\title{
Flt3 Ligand and CpG ODN Abrogate Impaired Antigen Presenting Cell Function by Aged Dendritic Cells
}

\author{
Mika Sasaki, ${ }^{1,2}$ and Kohtaro Fujihashi ${ }^{2}$ \\ ${ }^{1}$ Nihon University Graduate School of Dentistry at Matsudo, Oral Surgery, Matsudo, Chiba 271-8587, Japan \\ ${ }^{2}$ Department of Pediatric Dentistry and Microbiology, The Immunobiology Vaccine Center, The University of \\ Alabama at Birmingham, Birmingham, AL 35294-2170, USA
}

Correspondence to :

Mika Sasaki

E-mail : sasaki.mika@ nihon-u.ac.jp

Keywords :

dendritic cells, APC function, co- $^{-}$ stimulatory molecules, nasal immunization

\begin{abstract}
The immunodeficiency and increased risk of infection seen in elderly patients may be attributable to an alteration in the immune system. Since dendritic cells (DCs) play a key role for the induction of antigen (Ag)-specific immune responses, we hypothesize that upregulation of aged DCs function by flt3 ligand and $\mathrm{CpG}$ ODN abrogate for the induction of $\mathrm{Ag}^{-}$specific adjuvant immune responses. Mononuclear cells were isolated from spleen of BALB/c mice ( $>24$ months of age) and were stained with an array of fluorescence-conjugated $\mathrm{mAbs}$ in order to determine the frequencies of DCs by fluorescence activated cell sorter (FACS). The spleen from aged mice contained reduced frequencies $\mathrm{CD}^{+}$DCs and pDCs. Further, aged splenic DCs showed impaired APC function when compared with DCs from young adult mice. To compensate this age-associated alterations, flt3 ligand (FL) and CpG ODN were employed. When aged splenic DCs were cultured with recombinant (r) FL and $\mathrm{CpG}$ ODN, significant proliferative responses were induced, which is essentially identical to that of splenic DCs from young mice. Further, aged mice given nasal OVA plus FL plasmid (pFL) and CpG ODN showed high levels of OVA-specific IgG and IgA Abs in plasma which are comparable to those of young adult mice. Thus, the frequencies of $\mathrm{CD}^{+} \mathrm{DCs}$ and plasmacytoid DCs in spleen of aged mice were significantly increased after the immunization with $\mathrm{pFL}$ and $\mathrm{CpG}$ OND. More importantly, aged splenic DCs expressed increased frequencies of the costimulatory molecules. These results showed that a combination of $\mathrm{pFL}$ and $\mathrm{CpG}$ ODN treatment was an effective strategy to enhance impaired immunity that is seen in aged mice.
\end{abstract}

\section{Introduction}

Immune functions are known to deteriorate with age in several species. In fact, the risk and severity of infections are higher and the susceptibility to certain types of autoimmune diseases and cancer are greater in the elderly $(1,2)$, while responses to vaccination are diminished $(1,3,4)$. These studies provide evidence of disregulation and of an overall decline in host immunity in the elderly. In systemic immune compartments, the age-associated alterations have been studied extensively. Dysfunctions occur in both
$\mathrm{B}$ and $\mathrm{T}$ cells, though the latter are considered to be more susceptible to immunosenescence $(1,2,5,6)$.

It has been shown that dendritic cells (DCs) are central key player for the induction of innate and adoptive immunity. At least three to four subsets of DCs were identified and play distinct roles for the induction and regulation of immune responses. For example, Peyer's patch DCs expressing CD11c ${ }^{+}$, $\mathrm{CD}_{11 b^{+}}, \mathrm{CD}^{-}$are immature-type DCs which show high endocytic activity and low levels of MHC and B7 molecule expression (7). Thus, these CD11c ${ }^{+}$, 
$\mathrm{CD}_{11 b^{+}}, \mathrm{CD}^{-}$immature DCs are myeloid-type and expressing CCR6 for directing their migration toward the SED (8). Further, myeloid-type CD11b+ DCs are known to migrate into the $\mathrm{T}$ cells zone upon $\mathrm{Ag}$ uptake and in process of maturation by expressing CCR7 (8). Mature interdigitating CD11c ${ }^{+}, \mathrm{CD}_{11}{ }^{-}$, $\mathrm{CD}^{+}$DCs with low endocytic activity and high numbers of MHC class I and class II as well as B7 molecules were identified in the interfollicular $\mathrm{T}$ cell

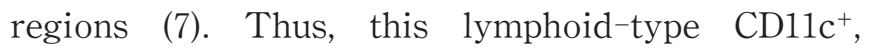

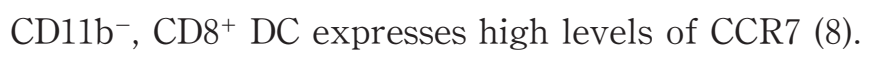
One subset of DCs was recently identified as plasmacytoid DCs (pDCs) in humans due to their structural resemblance to $\mathrm{Ig}^{-}$-secreting plasma cells (9). Murine pDCs were also identified as cells expressing $\mathrm{CD} 11 \mathrm{c}^{\text {low }}, \mathrm{B} 220^{\text {high }}, \mathrm{Gr}-1^{\text {1ow }}$ and showing plasmacytoid morphology. These murine pDCs also produce IFN$\alpha$ in response to viral stimulation (10-12) and can be differentiated in high numbers from bone marrow cells in the presence of FL (13-15).

Flt3 ligand (FL), which binds to the fms-like tyrosine kinase receptor Flt3/Flk2. FL mobilizes and stimulates myeloid and lymphoid progenitor cells (16), dendritic cells (DCs) (17), and natural killer (NK) cells (18). Although FL dramatically augments numbers of DCs in vivo, it fails to induce their activation (17). However, our previous study showed that $\mathrm{pFL}$ as nasal adjuvant expanded number of $\mathrm{CD} 8^{+} \mathrm{DCs}$ and up regulated their function for the induction of $\mathrm{Ag}^{-}$ specific immune responses (19). It has been shown that bacterial DNA, pathogen-associated molecular patterns (PAMPs), contain a significantly higher frequency of unmethylated cytosine-guanine dinucleotides (CpG) motifs $(20,21)$. The innate immune system recognizes these unmethylated $\mathrm{CpG}$ motifs through the toll-like receptor 9 (TLR9) which is mainly expressed by B cells and pDCs (22). Thus, CpG DNA induces the maturation and stimulation of professional pDCs as well as the subsequent $\mathrm{Ag}^{-}$ specific Th1-type and CTL responses $(23,24)$. Further, synthetic CpG ODN exhibit adjuvant activity through direct activation of TLR9 expressing pDCs (25-27).

Therefore, we hypothesize that impaired immune responses in aged mice is due to dysfunction of DCs and investigate whether a combination of $\mathrm{FL}$ and CpG ODN compensate altered DC function in aged mice.

\section{Materials and Methods}

Mice

Young adult (6-8 wks old) BALB/c mice were purchased from the Frederick Cancer Research Facility (National Cancer Institute, Frederick, MD). The retired $\mathrm{BALB} / \mathrm{c}$ male breeders (8 month old) were obtained from the Jackson Laboratory (Bar Harbor, ME). Upon arrival, all mice were immediately transferred to microisolators and maintained in horizontal laminar flow cabinets and provided sterile food and water ad libitum. Experiments were performed using young adult BALB/c mice between 6 and 8 weeks of aged mice, those over two years of age. The health of the mice was tested semi-annually and mice of all ages used in these experiments were free of bacterial and viral pathogens.

\section{In Vitro APC Function Analysis}

To assess whether aged DCs maintain antigen presentation activity, DCs were isolated from spleen of young adult and aged mice. CD11c ${ }^{+}$DCs from spleen and CLNs were purified by use of CD11c Microbeads (Miltenyi Biotec, Auburn, CA) and AutoMACS system. These purified DCs fractions

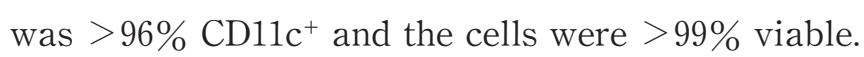
Splenic cells from DO11.10 Tg mice were stained with FITC conjugated anti-CD4 and PE labeled anti -KJ1.26 mAbs. OVA-specific naïve $\mathrm{CD}^{+} \mathrm{T}$ cells were then purified by FACSAria ${ }^{\mathrm{TM}}$. Splenic DCs $(1 \times$ $10^{5}$ cells) were suspended in RPMI 1640 (Cellgro; Mediatech, Washington, DC) supplemented with HEPES buffer $(10 \mathrm{mM})$, L-glutamine $(2 \mathrm{mM})$, nonessential amino acid solution $(10 \mathrm{ml} / \mathrm{L})$, sodium pyruvate $(10 \mathrm{mM})$, penicillin $(100 \mathrm{U} / \mathrm{ml})$, streptomycin $(100 \mu \mathrm{g} / \mathrm{ml})$, gentamicin $(80 \mu \mathrm{g} / \mathrm{ml})$, and $10 \%$ FCS (complete RPMI 1640) and incubated with OVA (1 $\mathrm{mg} / \mathrm{ml}$ ) for $24 \mathrm{hr}$. Complete RPMI containing OVA was replaced with $\mathrm{OVA}^{-}$-specific $\mathrm{CD} 4^{+} \mathrm{T}$ cells $\left(1 \times 10^{5}\right.$ cells) for 2 days. In some experiments, splenic DCs 
from young adult and aged mice were cultured with recombinant FL (10 $\mu \mathrm{g} / \mathrm{ml})$ and CpG ODN $0.5 \mu \mathrm{g} / \mathrm{ml})$ for 2 days in order to compare potent responsiveness of DCs to rFL and CpG ODN. To assess $\mathrm{CD} 4^{+} \mathrm{T}$ cell and $\mathrm{DC}$ proliferative responses, an aliquot of $0.5 \mu \mathrm{Ci}$ of tritiated $\left[{ }^{3} \mathrm{H}\right] \mathrm{TdR}$ (Amersham Biosciences, Arlington Heights, IL) was added during the final $18 \mathrm{~h}$ of incubation, and the amount of $\left[{ }^{3} \mathrm{H}\right] \mathrm{TdR}$ incorporation was determined by scintillation counting.

\section{Nasal Adjuvants and Immunization}

The plasmid pORF9-mFLt3L (pFL), consisting of the pORF9-mcs vector (pORF) plus the full-length mouse FL cDNA gene (InvivoGen, San Diego, CA) was used as nasal adjuvant (19). This plasmid DNA was purified using the QIAGEN Plasmid Giga Kits (QIAGEN, Valencia, CA). The Limulus amoebocyte lysate assay (BioWhittaker, Walkersville, MD) resulted in $<0.1$ endotoxin unit of LPS per $1 \mu \mathrm{g}$ of plasmid. A synthetic oligodeoxynucleotides (ODN) containing CpG motifs 1826 (5'-TCC ATG ACG TTC CTG ACG TT-3') (CpG ODN) was obtained from Coley Pharmaceutical Group (Wellesley MA) (27). Mice were immunized three times at weekly intervals nasally with $6.5 \mu \mathrm{l} /$ nostril PBS containing 100 $\mu \mathrm{g}$ of OVA (fraction V; Sigma-Aldrich, St. Louis, $\mathrm{MO})$ plus $50 \mu \mathrm{g}$ of $\mathrm{pFL}$ and $10 \mu \mathrm{g}$ of $\mathrm{CpG}$ ODN.

\section{OVA-specific Ab assay}

OVA-specific Ab levels in plasma was determined by ELISA $(19,28)$. Briefly, 96-well Falcon micro-test assay plates (BD Biosciences, Oxnard, CA) were coated with $1 \mathrm{mg} / \mathrm{ml}$ of OVA in PBS. After blocking with $1 \%$ BSA in PBS, 2-fold serial dilutions of the samples were added to each well. Following incubation overnight at $4^{\circ} \mathrm{C}$, horseradish peroxidase (HRP) -labeled goat anti-mouse $\mu, \gamma$, or $\alpha$ heavy chainspecific Abs [Southern Biotechnology Associates (SBA), Birmingham, AL] were added to wells. The color reaction was developed for 15 minutes at room

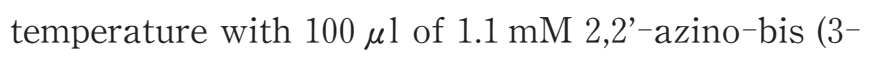
ethylbenz-thiazoline-6-sulfonic acid) in $0.1 \mathrm{M}$ citrate phosphate buffer ( $\mathrm{pH} 4.2$ ) containing $0.01 \% \quad \mathrm{H}_{2} \mathrm{O}_{2}$. Endpoint titers were expressed as the reciprocal $\log _{2}$ of the last dilution that gave an $\mathrm{OD}_{415} \mathrm{~nm}$ of 0.1 greater than the non-immunized samples.

\section{Flow cytometry analysis}

Aliquots of mononuclear cells were isolated from spleen and cervical lymph nodes (CLN) of mice immunized with OVA plus pFL and CpG ODN. Cells $\left(0.2-1.0 \times 10^{6}\right.$ cells $)$ were stained with FITC-conjugated anti-mouse $\mathrm{CD} 8, \mathrm{CD} 11 \mathrm{c}$, or $\mathrm{B} 220 \mathrm{mAbs}, \mathrm{PE}-$ labeled anti-mouse CD40, CD80, or CD86 mAbs (BD PharMingen), and biotinylated anti-mouse CD11c mAbs (BD PharMingen), followed by PerCP-Cy5.5streptavidin. The samples were then subjected to FACS analysis (FACS Calibur ${ }^{\mathrm{TM}}$; BD Bioscience).

\section{Statistical analysis}

The results are expressed as the mean \pm 1 standard error of the mean (SEM). The experimental mouse groups were compared with control mice using an unpaired Mann-Whitney $U$ test with Statview software (Abacus Concepts, Berkley, CA) designed for Macintosh computers. $P$ values of $<0.05$ were considered significant.

\section{Results}

Impaired APC function by aged DCs

We initially examined whether splenic DCs from aged mice maintain normal APC function that is comparable to DCs from young adult mice. When OVA treated splenic DCs from aged mice were incubated with $\mathrm{CD}^{+}{ }^{+} \mathrm{T}$ cells from naïve DO11.10 mice, significant $\mathrm{CD}^{+} \mathrm{T}$ cell proliferative responses were noted. However, these responses were markedly lower than those with splenic DCs from young adult mice (Fig. 1). Similarly, when aged DCs from Peyer's patches of aged mice were examined for their ability to stimulate $\mathrm{CD}^{+} \mathrm{T}$ cells, impaired APC function was also noted (data not shown). These results show that age-related alteration was clearly induced in DCs as the major APC.

\section{Reduced numbers of DCs in spleen of aged mice}

We next examined the frequency of DCs in spleen of two-yr old and young adult BALB/c mice. Splenic 


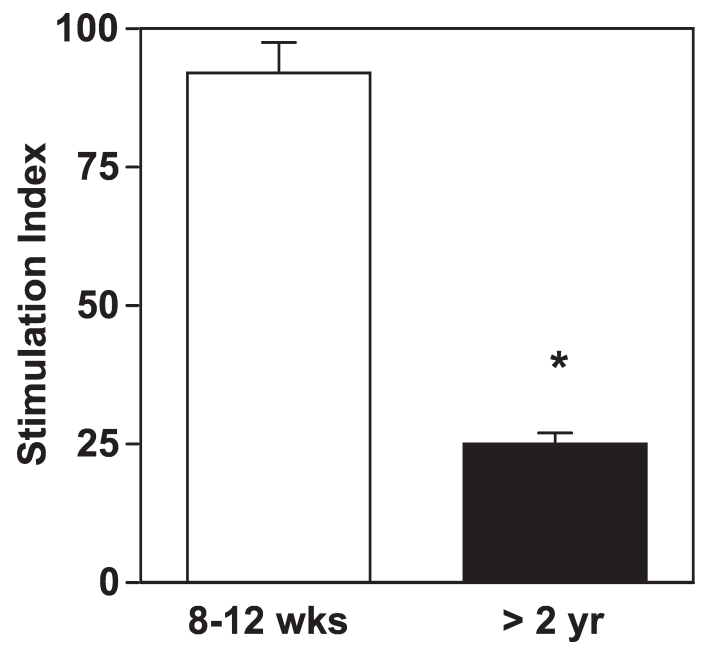

Fig. 1. Comparison of APC function by DCs from aged and young adult mice. CD11c ${ }^{+}$DCs from spleen and CLNs were purified by use of CD11c Microbeads (Miltenyi Biotec, Auburn, CA) and AutoMACS system. Splenic cells from DO11.10 Tg mice were stained with FITC conjugated anti-CD4 and PE labeled anti-KJ1.26 mAbs. OVA-specific naïve $\mathrm{CD}^{+}{ }^{+} \mathrm{T}$ cells were then purified by FACSAria ${ }^{\mathrm{TM}}$. Splenic DCs $\left(1 \times 10^{5}\right.$ cells $)$ were suspended in complete RPMI 1640 and incubated with OVA $(1 \mathrm{mg} / \mathrm{ml})$ for $24 \mathrm{hr}$. Complete RPMI containing OVA was replaced with $\mathrm{OVA}^{-}$-specific $\mathrm{CD}^{+}{ }^{+} \mathrm{T}$ cells $\left(1 \times 10^{5}\right.$ cells $)$ for 2 days. To assess $\mathrm{CD}^{+}{ }^{+} \mathrm{T}$ cell proliferative responses, an aliquot of $0.5 \mu \mathrm{Ci}$ of tritiated $\left[{ }^{3} \mathrm{H}\right] \mathrm{TdR}$ was added during the final $18 \mathrm{~h}$ of incubation, and the amount of $\left[{ }^{3} \mathrm{H}\right] \mathrm{TdR}$ incorporation was determined by scintillation counting. The stimulation index was determined as cpm of wells with DCs/wells without DCs (control). The results represent the individual values from three separate experiments. ${ }^{*} p<0.05$, when compared with young adult mice.

mononuclear cells from both groups of mice were stained with a combination of anti-CD11c, anti-B220, anti-CD8 and anti-CD11b mAbs in order to identify the major three subsets of DCs: 1) lymphoid type DCs $\left.\left.\left(\mathrm{CD}_{11 \mathrm{c}^{+}} \mathrm{CD} 8^{+}\right) ; 2\right) \mathrm{pDCs}\left(\mathrm{CD}_{11 \mathrm{c}^{+}} \mathrm{B} 220^{+}\right) ; 3\right)$ myeloid type $\mathrm{DCs}\left(\mathrm{CD} 11 \mathrm{c}^{+} \mathrm{CD} 11 \mathrm{~b}^{+}\right)$. When samples were subjected to flow cytometric analysis, significantly decreased frequency of $\mathrm{CD}_{11 \mathrm{c}^{+}} \mathrm{DCs}$ were noted in spleen of aged mice in comparison to that of young adult mice (Table 1). When subsets of DCs from aged mice were analyzed, the frequency of $\mathrm{CD}^{+}$DCs and pDCs significantly decreased (Table 1 ), while the frequencies of splenic myeloid type DCs were increased in comparison to those in young adult mice. These results indicate that age related altered APC function of splenic DCs may be due to the decreased frequency of $\mathrm{CD} 8^{+} \mathrm{DC}$ and $\mathrm{pDC}$ subsets in aged spleen.
Table 1. Comparison of the frequency of DC subsets in Spleen

\begin{tabular}{|c|c|c|c|c|}
\hline Age of Mice & $\mathrm{CD}_{11 \mathrm{c}^{+}}$ & $\begin{array}{c}\mathrm{CD}_{11 \mathrm{c}^{+} \mathrm{CD} 8^{+}} \\
\text {(Lymphoid DCs) }\end{array}$ & $\begin{array}{c}\mathrm{CD}^{2} 1 \mathrm{c}^{+} \mathrm{B} 220^{+} \\
(\mathrm{pDC})\end{array}$ & $\begin{array}{l}\mathrm{CD}_{11 \mathrm{c}^{+} \mathrm{CD} 11 \mathrm{~b}^{+}} \\
\text {(myeloid DCs) }\end{array}$ \\
\hline 8-12 weeks & $4.35 \pm 0.15^{\mathrm{a}}$ & $1.86 \pm 0.26$ & $2.21 \pm 0.07$ & $0.31 \pm 0.11$ \\
\hline$>24$ months & $3.34 \pm 0.08^{*}$ & $0.45 \pm 0.04^{*}$ & $1.73 \pm 0.08^{*}$ & $1.16 \pm 0.17^{*}$ \\
\hline
\end{tabular}

${ }^{\text {aPercent }}$ of Total Lymphocyte

${ }^{*} p<0.05$, when compared with young adult mice.

\section{Aged DCs respond to FL and CDG ODN}

Since the numbers of two major subsets of splenic DCs were diminished by aging, it is important to examine whether FL and CpG ODN compensate this age-related alteration. In this regard, we initially test whether aged splenic DCs are able to respond to FL and CpG ODN stimulation. Purified splenic DCs from aged and young adult mice were cultured with FL $(10 \mu \mathrm{g} / \mathrm{ml})$ and CpG ODN $(0.5 \mu \mathrm{g} / \mathrm{ml})$ for 2 days. Proliferative responses by DCs were determined by amount of $[3 \mathrm{H}]-\mathrm{TdR}$ incorporation. $\mathrm{FL}$ and $\mathrm{CpG}$ ODN stimulated DCs from spleen of aged mice resulted in high levels of proliferative responses which is comparable to those of young adult mice (Fig. 2).

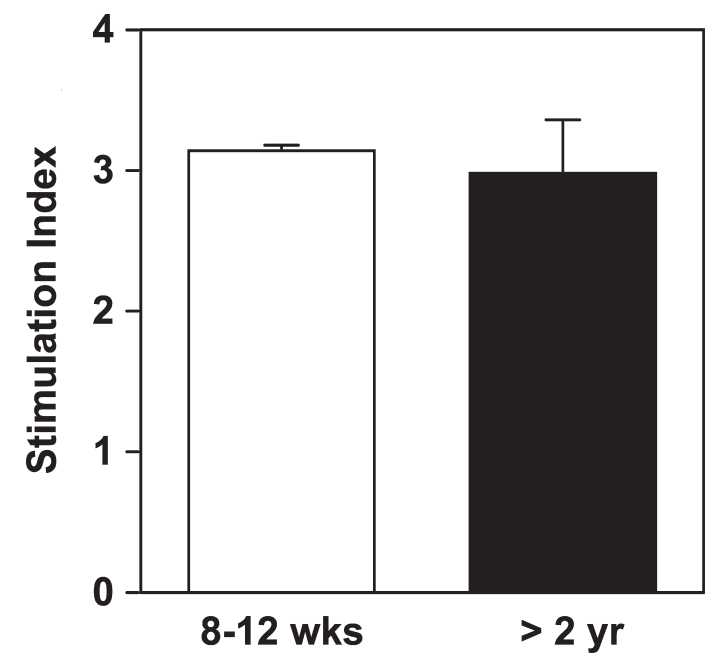

Fig. 2. DC proliferative responses induced by $\mathrm{rFL}$ and $\mathrm{CpG}$ ODN. Splenic mononuclear cells were stained with anti-and CD11c Microbeads were then purified by AutoMACS. Purified $\mathrm{CD}_{11} \mathrm{c}^{+} \mathrm{DCs}$ from spleen of aged and young adult mice were cultured with or without $\mathrm{rFL}(10 \mu \mathrm{g} / \mathrm{ml})$ and $\mathrm{CpG}$ ODN $(0.5$ $\mu \mathrm{g} / \mathrm{ml})$ for 2 days. The amount of $\left[{ }^{3} \mathrm{H}\right]-\mathrm{TdR}$ incorporation was determined by scintillation counting. The stimulation index was determined as cpm of wells with FL and CpG ODN/ wells without FL and $\mathrm{CpG}$ ODN (control). The results represent the individual values from three separate experiments. 
These results show that aged DCs are capable to respond to the stimulation of $\mathrm{FL}$ and $\mathrm{CpG} \mathrm{ODN}$, which is equivalent to that seen in young adults mice.

Nasal immunization with OVA plus $p F L$ and CpG ODN induces Ag-specific antibody responses in plasma of aged mice

Next, we examined whether in vivo application of FL and CpG ODN compensate impaired APC function of aged DCs. Thus, aged mice were nasally immunized with OVA only or OVA plus pFL and $\mathrm{CpG} \mathrm{ODN}$ and $\mathrm{Ag}^{-}$specific $\mathrm{Ab}$ responses were examined. High level of anti-OVA IgG Ab response was seen in aged mice given nasal OVA plus pFL and CpG ODN which is comparable to that of young adult mice (Fig. 3). Further, OVA-specific IgA Ab responses were also detected in plasma of aged mice given nasal $\mathrm{pFL}$ and $\mathrm{CpG}$ ODN as mucosal adjuvant (Fig. 3). On the other hand, aged mice given OVA only failed to induce any OVA-specific Ab responses (Fig. 3). These results indicate that nasally administered $\mathrm{pFL}$ and $\mathrm{CpG}$ ODN effectively upregulate aged DC function for the subsequent induction of $\mathrm{Ag}^{-}$-specific $\mathrm{Ab}$ responses.
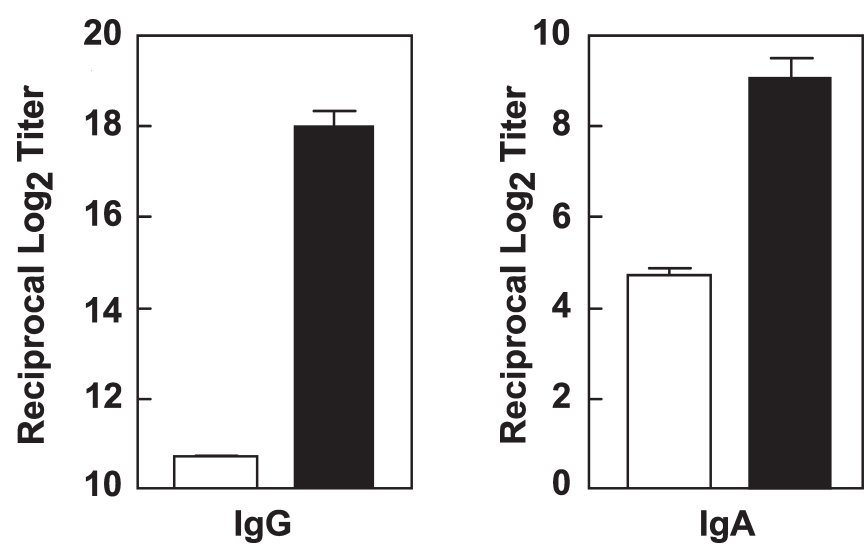

Fig. 3. OVA-specific $\mathrm{Ab}$ responses in plasma of aged mice given nasal OVA with $(\boldsymbol{\square}) /$ without $(\square) \mathrm{pFL}$ and CpG ODN. Each mouse group was nasally immunized weekly for 3 consecutive weeks with $100 \mu \mathrm{g}$ of OVA plus $50 \mu \mathrm{g}$ of pFL and 10 $\mu \mathrm{g}$ of $\mathrm{CpG}$ ODN as mucosal adjuvants. Seven days after the final immunization, the levels of $\mathrm{OVA}^{-}$specific IgG and $\operatorname{IgA}$ $\mathrm{Ab}$ responses in plasma were determined by an $\mathrm{OVA}^{-}$specific ELISA. Values are shown as the mean \pm SEM taken from 6 mice in each experimental group.
Nasal administration of $p F L$ and $C D G O D N$ expands DCs in aged mice

Since significant levels of Ag-specific $\mathrm{Ab}$ responses were induced in aged mice, it is important to investigate the frequency of $\mathrm{CD} 11 \mathrm{c}^{+} \mathrm{DCs}$. In this regard, mononuclear cells were isolated from CLN in addition to spleen since CLN is the main draining lymph nodes of nasal immunization. Significantly increased frequency of CD11c expressing DCs was noted in CLN and spleen of aged mice given nasal OVA plus pFL and CpG ODN when compared with mice give nasal OVA only (Fig. 4). It is interesting to note that the change in CLN was more significant than that in spleen. These results clearly show that nasal application of $\mathrm{pFL}$ and $\mathrm{CpG}$ ODN compensate decreased number of $\mathrm{DC}$ in aged mice for the induction of $\mathrm{Ag}^{-}$specific immune responses.

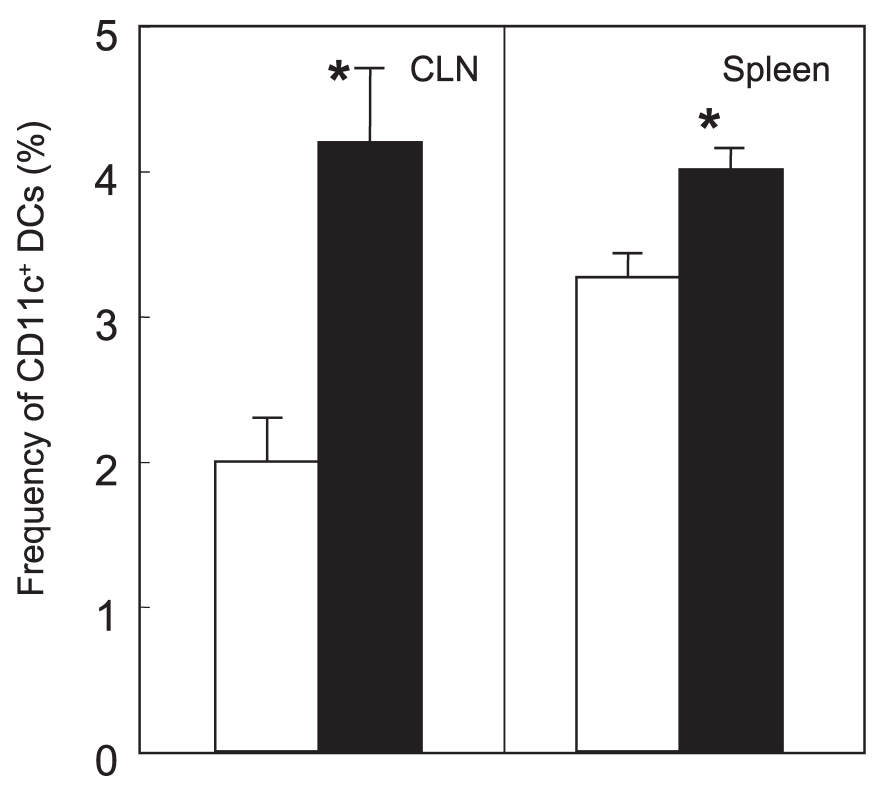

Fig. 4. The frequency of CD11c $\mathrm{c}^{+} \mathrm{DCs}$ in spleen of aged mice given nasal OVA with ( $\mathbf{\square})$ without $(\square) \mathrm{pFL}$ and CpG ODN. Mice were nasally immunized weekly for 3 consecutive weeks with $100 \mu \mathrm{g}$ of OVA plus of pFL (50 $\mu \mathrm{g})$ and CpG ODN (10 $\mu \mathrm{g})$. Mononuclear cell from spleen were isolated 7 days after the last immunization and were stained with biotinylated antiCD11c mAb followed by Cy5.5-streptavidin. The frequency of CD11c expressing DCs was determined by FACS Calibur ${ }^{\mathrm{TM}}$. Values are shown as the mean \pm SEM of 6 mice in each experimental group. ${ }^{*} p<0.05$, when compared with aged mice without $\mathrm{pFL}$ and $\mathrm{CpG}$ ODN. 
Nasal pFL and CpG ODN target $C D 8^{+} D C s$ and pDCs in aged mice

Since increased frequencies of $\mathrm{CD}_{11 \mathrm{c}^{+}}$DCs were seen in the spleen and CLN of aged mice given nasal $\mathrm{pFL}$ and $\mathrm{CpG}$ ODN, it is important to examine that which subsets of DCs were increased and upregulated. In order to characterize the phenotype of these expanded DCs, we assessed cell surface expression by $\mathrm{CD}_{11 \mathrm{c}^{+}} \mathrm{DCs}$ [CD8, B220, MHC class II (MHC II), CD40, CD80, and CD86] in spleen and CLN. Interestingly, the distribution of $\mathrm{CD} 11 \mathrm{~b}^{+} \mathrm{DC}$ subset was not changed after nasal pFL and $\mathrm{CpG}$ ODN. However, both spleen and CLN showed increased frequencies of the $\mathrm{CD}^{+} \mathrm{DC}\left(\mathrm{CD} 11 \mathrm{c}^{+} \mathrm{CD}^{+}\right)$and $\mathrm{pDC}\left(\mathrm{CD} 11 \mathrm{c}^{+}\right.$ $\mathrm{B} 220^{+}$) subsets (Table 2). Further, higher levels CD40, CD80 and CD86 molecules were expressed by $\mathrm{CD} 8^{+}$ $\mathrm{DCs}$ and $\mathrm{pDCs}$ of mice given nasal $\mathrm{pFL}$ and $\mathrm{CpG}$ ODN when compared with those of mice given OVA only (Table 3). Taken together, these results indicate that nasal administration of $\mathrm{pFL}$ and $\mathrm{CpG}$ ODN preferentially expands and stimulats $\mathrm{CD} 8^{+} \mathrm{DCs}$ and pDCs subsets in CLN and spleen for the induction of $\mathrm{Ag}^{-}$specific $\mathrm{Ab}$ responses in aged mice.

Table 2. The frequency of DCs in two-year old mice given nasal OVA plus $\mathrm{pFL}$ and $\mathrm{CpG}$ ODN

\begin{tabular}{|c|c|c|c|c|}
\hline & \multirow{3}{*}{ Nasal OVA plus } & \multicolumn{3}{|c|}{ Percents of total lymphocyte } \\
\hline & & \multicolumn{3}{|c|}{$\mathrm{CD}_{11 \mathrm{c}^{+} \mathrm{DCs}}$} \\
\hline & & $\mathrm{CD}^{+}$ & $\mathrm{B} 220^{+}$ & $\mathrm{CD} 11 \mathrm{~b}^{+}$ \\
\hline \multirow{2}{*}{ Spleen } & None & $0.45 \pm 0.03$ & $1.73 \pm 0.08$ & $1.16 \pm 0.13$ \\
\hline & $\mathrm{pFL} / \mathrm{CpG}$ ODN & $1.00 \pm 0.07^{*}$ & $2.45 \pm 0.21^{*}$ & $1.18 \pm 0.28$ \\
\hline \multirow{2}{*}{ CLN } & None & $0.41 \pm 0.05$ & $0.8 \pm 0.01$ & $0.60 \pm 0.10$ \\
\hline & $\mathrm{pFL} / \mathrm{CpG}$ ODN & $1.50 \pm 0.10^{*}$ & $1.80 \pm 0.20^{*}$ & $0.80 \pm 0.20$ \\
\hline
\end{tabular}

${ }^{*} p<0.05$, when compared with mice given OVA only

Table 3. The frequency of costimulatory molecule expressing DCs in two-year old mice given nasal OVA plus $\mathrm{pFL}$ and $\mathrm{CpG}$ ODN

\begin{tabular}{ccccc}
\hline \multirow{2}{*}{ Nasal OVA plus } & \multicolumn{3}{c}{$\mathrm{CD}_{11 \mathrm{c}^{+} \mathrm{DCs}}$} \\
\cline { 3 - 5 } & & $\mathrm{CD} 40^{+}$ & \multicolumn{1}{c}{$\mathrm{CD} 80^{+}$} & \multicolumn{1}{c}{$\mathrm{CD} 86^{+}$} \\
\hline \multirow{2}{*}{ Spleen } & None & $2.66 \pm 0.07$ & $0.09 \pm 0.02$ & $0.08 \pm 0.04$ \\
& $\mathrm{pFL} / \mathrm{CpG}$ ODN & $2.90 \pm 0.01$ & $0.30 \pm 0.02^{*}$ & $0.53 \pm 0.04^{*}$ \\
\hline \multirow{2}{*}{$\mathrm{CLN}$} & None & $0.70 \pm 0.06$ & $0.30 \pm 0.09$ & $0.03 \pm 0.01$ \\
& $\mathrm{pFL} / \mathrm{CpG}$ ODN & $2.50 \pm 0.20^{*}$ & $1.30 \pm 0.06^{*}$ & $0.70 \pm 0.06^{*}$ \\
\hline
\end{tabular}

${ }^{*} p<0.05$, when compared with mice given OVA only

\section{Discussion}

The present study shows that splenic DCs from aged mice possess lower APC activity than those of young adult mice. Thus, the number of DCs was decreased in spleen of aged mice. Flow cytometric analyses revealed that $\mathrm{CD} 8^{+} \mathrm{DCS}$ and $\mathrm{pDC}$ subsets were significantly affected by aging among different subsets of DCs. When DC targeted FL and CpG ODN were employed via the nasal route for the compensation of age-related alteration of DC function, $\mathrm{pDC}$ and $\mathrm{CD} 8^{+} \mathrm{DC}$ population were selectively up-regulated and their numbers were increased in CLN and spleen of aged mice. Further, $\mathrm{Co}^{-}$administered $\mathrm{Ag}^{-}$ specific $\mathrm{Ab}$ responses were also induced in aged mice given nasal $\mathrm{pFL}$ and $\mathrm{CpG} \mathrm{ODN}$. These results are first to show that impaired aged DC function can be converted by DC targeting FL and CpG ODN.

Recent studies have also shown that aged DCs exhibit less ability to trigger $\mathrm{T}$ and $\mathrm{B}$ cells $(29,30)$. On the other hand, others have shown intact APC functions in aged DCs (31-33). Thus, the quality of APC function by aged DCs is a controversial issue. However, our past study that lends the most support for impaired APC function by aged DCs showed that aged mice resulted in impaired $\mathrm{Ag}^{-}$specific $\mathrm{Ab}$ responses when orally immunized with OVA plus $\mathrm{nCT}$ as mucosal adjuvant. In this regard, it is logical to predict that DCs from aged mice would be less able to stimulate $\mathrm{CD} 4^{+} \mathrm{T}$ cells than those of young adult mice. Indeed, our study clearly showed that aged splenic DC exhibited lower APC function when co cultured with OVA-specific $\mathrm{CD}^{+}{ }^{+} \mathrm{T}$ cells. Thus, lower $\mathrm{T}$ cell proliferative responses were seen in $\mathrm{CD}^{+} \mathrm{T}$ cell cultures incubated with DCs from aged mice.

Our results showed that APC functions of splenic DCs altered in aged mice. Further, the frequencies of $\mathrm{CD}^{+}$DCs and pDCs were significantly reduced in spleen of aged mice. In this regard, we next examined the stimulatory potency of aged splenic DCs other than Ag. We employed FL and CpG ODN to stimulate aged DCs since FL are known to expand $\mathrm{CD} 8^{+}$ DC population (19) and CpG ODN selectively to stimulate pDCs (22-24). Our results showed that 
proliferative response by aged DCs is comparable to DCs of young adult mice. To confirm this finding, we are currently testing Flt3 and TLR9 expression by aged DCs since these receptors mediate the signaling pathways are essential for the upregulation of aged DCs. Flt3 expression by aged pDCs is determined by flow cytometry using PE conjugated anti-Flt3 (CD135) mAb together with FITC labeled anti-CD8, Allophycocyanin-conjugated anti-B220 and biotinylated anti-CD11c mAbs followed by PerCPCy5.5-streptavidin. Further, DCs are purified from spleen of both young adult and aged mice and then be subjected to Flt3- and TLR9-specific real-time quantitative RT-PCR analysis. Our preliminary results showed that both Flt3 and TLR9 expression by aged DCs are comparable to those of young adult mice (data not shown). These results show that a combination of FL and $\mathrm{CpG}$ ODN is potent stimulatory signals of aged DCs for the induction of $\mathrm{Ag}^{-}$-specific immune responses. Although it would be logical to predict that diminished APC functions by aged DCs would indicate an impaired innate signaling by $\mathrm{FL}$ and $\mathrm{CpG}$, we hypothesize that these responses are not correlated with each other. To support this, it has been suggested that age-associated deficiency can be corrected by the appropriate cytokine stimulation (30). Indeed, it has been shown that aged DCs derived by in vitro GM-CSF treatment showed intact APC activity $(32,33)$. Further, it was reported that aged DCs responded well to FL stimulation (34).

It has been shown that $\mathrm{Ag}^{-}$-specific $\operatorname{IgA} \mathrm{B}$ cell responses play a central role in the induction of mucosal immunity to infectious diseases (35). However, mucosal immunity is affected in aging and susceptibility to infectious diseases is increased in the elderly $(4,36)$. In fact, in elderly human pathogens which invade through mucosal surfaces, such as the influenza virus and the bacterial pathogen Streptococcus pneumoniae (S. pneumoniae), cause more severe and more frequently lethal infections $(3,37,38)$. It has been shown that aged animals given oral $\mathrm{nCT}$ contained significantly lower anti-CT-B IgA Ab responses than did those from identically immunized young rats $(39,40)$ and rhesus macaques $(41)$. When aged mice were orally immunized with $\mathrm{nCT}$ as mucosal adjuvant, $\mathrm{Ag}^{-}$specific $\mathrm{S}-\mathrm{IgA} \mathrm{Ab}$ responses were also lower than in young mice $(42,43)$. These results clearly indicate that $\mathrm{Ag}^{-}$-specific mucosal Ig $\mathrm{A}$ $\mathrm{Ab}$ responses are diminished in aged animals. Although the significant reductions in $\mathrm{Ag}^{-}$-specific $\mathrm{S}$ $-\operatorname{IgA~Ab}$ responses in the elderly is clear evidence for mucosal senescence, our previous study showed potency of nasal immunization regimen for the induction of $\mathrm{Ag}^{-}$-specific $\mathrm{Ig} \mathrm{A} \mathrm{Ab}$ responses in aged mice when compared with oral immunization strategy (28, 43). Even though the most potent mucosal adjuvant, such as $\mathrm{nCT}$ failed to induce $\mathrm{Ag}^{-}$-specific $\operatorname{Ig} \mathrm{A} \mathrm{Ab}$ responses in plasma as well as external secretions (28). These studies indicate that although nasal immunization is a potent immunization regiment to induce $\mathrm{Ag}^{-}$-specific $\operatorname{Ig} \mathrm{A} \mathrm{Ab}$ responses, it would be require another novel nasal adjuvant for the induction of mucosal immunity in aged mice. Our present study showed significant findings that nasal application of $\mathrm{pFL}$ and $\mathrm{CpG}$ ODN could induce $\mathrm{Ag}^{-}$-specific $\mathrm{IgA} \mathrm{Ab}$ responses in plasma of aged mice. These results also indicate that a combination of $\mathrm{pFL}$ and CPG ODN would be a potent DC targeting mucosal adjuvant for the induction of $\mathrm{Ag}^{-}$-specific mucosal $\mathrm{Ig} \mathrm{A} \mathrm{Ab}$ responses in addition to systemic immunity.

In summary, our studies show that impaired APC function could be corrected by FL and $\mathrm{CpG}$ ODN. Thus, nasal application of pFL and $\mathrm{CpG}$ ODN resulted in the increased frequency of DC subsets and the induction of $\mathrm{Ag}^{-}$-specific $\mathrm{IgG}$ and $\mathrm{Ig} \mathrm{A} \mathrm{Ab}$ responses in plasma of aged mice. To this end, our current finding would light on the shade in the development of effective mucosal vaccine for the elderly.

NIH Grants DE 12242, AI 18958, DC 04976 and AI 43197 supported this research.

\section{References}

1. Castle SC: Clinical relevance of age-related immune dysfunction. Clin Infect Dis, 31: 578-585, 2000.

2. Miller RA: The aging immune system: primer and prospectus. Science, 273 : 70-74, 1996.

3. Bernstein E, Kaye D, Abrutyn E, Gross P, Dorfman M, Murasko DM : Immune response to influenza vaccination in a large healthy elderly population. Vaccine, 17 : 
82-94, 1999.

4. Powers DC: Immunological principles and emerging strategies of vaccination for the elderly. J Am Geriatr Soc, 40 : 81-94, 1992.

5. Globerson A, Effros RB : Ageing of lymphocytes and lymphocytes in the aged. Immunol Today, $21: 515^{-}$ 521, 2000.

6. Solana R, Pawelec G: Molecular and cellular basis of immunosenescence. Mech Ageing Dev, 102: 115-129, 1998.

7. Kelsall BL, Strober W : Distinct populations of dendritic cells are present in the subepithelial dome and $\mathrm{T}$ cell regions of the murine Peyer's patch. J Exp Med, 183 : 237-247, 1996.

8. Iwasaki A, Kelsall BL : Localization of distinct Peyer's patch dendritic cell subsets and their recruitment by chemokines macrophage inflammatory protein (MIP)$3 \alpha, \mathrm{MIP}-3 \beta$ and secondary lymphoid organ chemokine. J Exp Med, 191 : 1381-1394, 2000.

9. Facchetti F, Candiago E, Vermi W: Plasmacytoid monocytes express IL-3-receptor $\alpha$ and differentiate into dendritic cells. Histopathology, 35 : 88-89, 1999.

10. Asselin-Paturel C, Boonstra A, Dalod M, Durand I, Yessaad N, Dezutter-Dambuyant C, Vicari A, O'Garra A, Biron C, Briere F, Trinchieri G: Mouse type I IFN -producing cells are immature APCs with plasmacytoid morphology. Nat Immunol, 2 : 1144-1150, 2001.

11. Bjorck P: Isolation and characterization of plasmacytoid dendritic cells from Flt3 ligand and granulocyte-macrophage colony-stimulating factortreated mice. Blood, 98 : 3520-3526, 2001.

12. Nakano H, Yanagita M, Gunn MD : CD11c ${ }^{+} \mathrm{B} 220^{+} \mathrm{Gr}$ $-1^{+}$cells in mouse lymph nodes and spleen display characteristics of plasmacytoid dendritic cells. J Exp Med, 194 : 1171-1178, 2001.

13. Brawand P, Fitzpatrick DR, Greenfield BW, Brasel K, Maliszewski CR, De Smedt T: Murine plasmacytoid pre-dendritic cells generated from Flt3 ligand-supplemented bone marrow cultures are immature APCs. J Immunol, 169 : 6711-6719, 2002.

14. Gilliet M, Boonstra A, Paturel C, Antonenko S, Xu XL, Trinchieri G, O'Garra A, Liu YJ : The development of murine plasmacytoid dendritic cell precursors is differentially regulated by FLT3-ligand and granulocyte/macrophage colony-stimulating factor. J Exp Med, 195: 953-958, 2002.

15. Manfra DJ, Chen SC, Jensen KK, Fine JS, Wiekowski MT, Lira SA : Conditional expression of murine flt3 ligand leads to expansion of multiple dendritic cell subsets in peripheral blood and tissues of transgenic mice. J Immunol, 170 : 2843-2852, 2003.

16. Brasel K, McKenna HJ, Morrissey PJ, Charrier K, Morris AE, Lee CC, Williams DE, Lyman SD:
Hematologic effects of flt3 ligand in vivo in mice. Blood, 88: 2004-2012, 1996.

17. Maraskovsky E, Brasel K, Teepe M, Roux ER, Lyman $\mathrm{SD}$, Shortman K, McKenna HJ : Dramatic increase in the numbers of functionally mature dendritic cells in Flt3 ligand-treated mice: multiple dendritic cell subpopulations identified. J Exp Med, 184 : 1953-1962, 1996.

18. Yu H Fehniger TA, Fuchshuber P, Thiel KS, Vivier E, Carson WE, Caligiuri MA: Flt3 ligand promotes the generation of a distinct $\mathrm{CD} 34^{+}$human natural killer cell progenitor that responds to interleukin-15. Blood, 92: 3647-3657, 1998.

19. Kataoka K, McGhee JR, Kobayashi R, Fujihashi K, Shizukuishi S, Fujihashi K : Nasal Flt3 ligand cDNA elicits $\mathrm{CD}_{11 \mathrm{c}^{+}} \mathrm{CD}^{+}$dendritic cells for enhanced mucosal immunity. J Immunol, 172 : 3612-3619, 2004.

20. Cardon LR, Burge C, Clayton DA, Karlin S: Pervasive $\mathrm{CpG}$ suppression in animal mitochondrial genomes. Proc Natl Acad Sci USA, 91: 3799-3803, 1994.

21. Razin A, Friedman J : DNA methylation and its possible biological roles. Prog Nucleic Acid Res Mol Biol, 25 : 33-52, 1981.

22. Hemmi H, Takeuchi O, Kawai T, Kaisho T, Sato S, Sanjo H, Matsumoto M, Hoshino K, Wagner $H$, Takeda K, Akira S: A Toll-like receptor recognizes bacterial DNA. Nature, 408: 740-745, 2000.

23. Klinman DM: Immunotherapeutic uses of $\mathrm{CpG}$ oligodeoxynucleotides. Nat Rev Immunol, 4 : 249-258, 2004.

24. Wagner $\mathrm{H}$ : Bacterial $\mathrm{CpG}$ DNA activates immune cells to signal infectious danger. Adv Immunol, 73 : 329-368, 1999.

25. Klinman DM, Barnhart KM, Conover J : CpG motifs as immune adjuvants. Vaccine, 17 : 19-25, 1999.

26. Krieg AM, Yi AK, Matson S, Waldschmidt TJ, Bishop GA, Teasdale R, Koretzky GA, Klinman DM : CpG motifs in bacterial DNA trigger direct $\mathrm{B}^{-}$cell activation. Nature, 374 : 546-549, 1995.

27. Moldoveanu Z, Love-Homan L, Huang WQ, Krieg AM : CpG DNA, a novel immune enhancer for systemic and mucosal immunization with influenza virus. Vaccine, 16 : 1216-1224, 1998.

28. Hagiwara Y, McGhee JR, Fujihashi K, Kobayashi R, Yoshino N, Kataoka K, Etani Y, Kweon M-N, Tamura S, Kurata T, Takeda Y, Kiyono H, Fujihashi K: Protective mucosal immunity in aging is associated with functional $\mathrm{CD}^{+}{ }^{+} \mathrm{T}$ cells in nasopharyngeal-associated lymphoreticular tissue. J Immunol, 170 : 1754 -1762, 2003.

29. Pietschmann P, Hahn P, Kudlacek S, Thomas R, Peterlik M: Surface markers and transendothelial migration of dendritic cells from elderly subjects. Exp 
Gerontol, 35 : 213-224, 2000.

30. Plackett TP, Boehmer ED, Faunce DE, Kovacs EJ : Aging and innate immune cells. J Leukoc Biol, 76 : 291 $-299,2004$.

31. Komatsubara S, Cinader B, Muramatsu S: Polymorphism of age-related changes in stimulatory capacity of murine dendritic cells. Mech Ageing Dev, 37 : 163173, 1986.

32. Lung TL, Saurwein-Teissl M, Parson W, Schonitzer D, Grubeck-Loebenstein B: Unimpaired dendritic cells can be derived from monocytes in old age and can mobilize residual function in senescent $\mathrm{T}$ cells. Vaccine, 18: 1606-1612, 2000.

33. Steger MM, Maczek C, Grubeck-Loebenstein B: Morphologically and functionally intact dendritic cells can be derived from the peripheral blood of aged individuals. Clin Exp Immunol, 105 : 544-550, 1996.

34. Shurin GV, Chatta GS, Tourkova IL, Zorina TD, Esche C, Shurin MR: Regulation of dendritic cell expansion in aged athymic nude mice by FLT3 ligand. Exp Gerontol, 39 : 339-348, 2004.

35. Fujihashi K, McGhee JR: Mucosal immunity and tolerance in the elderly. Mech Ageing Dev, 125 : 889898, 2004.

36. Schmucker DL, Heyworth MF, Owen RL, Daniels CK :
Impact of aging on gastrointestinal mucosal immunity. Dig Dis Sci, 41: 1183-1193, 1996.

37. Mufson MA : Pneumococcal Pneumonia. Curr Infect Dis Rep, $1: 57-64,1999$.

38. Webster RG: Immunity to influenza in the elderly. Vaccine, 18: 1686-1689, 2000.

39. Schmucker DL, Daniels CK, Wang RK, Smith K: Mucosal immune response to cholera toxin in ageing rats. I. Antibody and antibody-containing cell response. Immunology, 64 : 691-695, 1988.

40. Thoreux K, Owen RL, Schmucker DL: Intestinal lymphocyte number, migration and antibody secretion in young and old rats. Immunology, 101: 161-167, 2000.

41. Taylor LD, Daniels CK, Schmucker DL : Ageing compromises gastrointestinal mucosal immune response in the rhesus monkey. Immunology, 75 : 614-618, 1992.

42. Enioutina EY, Visic VD, Daynes RA : Enhancement of common mucosal immunity in aged mice following their supplementation with various antioxidants. Vaccine, 18: 2381-2393, 2000.

43. Koga T, McGhee JR, Kato H, Kato R, Kiyono H, Fujihashi K : Evidence for early aging in the mucosal immune system. J Immunol, 165 : 5352-5359, 2000. 